http://dx.doi.org/10.12775/szhf.2017.050

\title{
Filip Springer, 13 pięter, Wydawnictwo Czarne, Wołowiec 2015, ss. 283
}

\author{
„Architekt jest jakby producentem teatralnym, \\ człowiekiem aranżującym scenę, \\ na której toczy się nasze życie. \\ Od tego, w jaki sposób to zrobi, \\ zależy nieskończenie wiele"1.
}

Filip Springer jest pisarzem, reporterem i fotografem, a także felietonistą współpracującym z największymi polskimi tytułami prasowymi. Talent pisarski Springera potwierdzają liczne wyróżnienia (reportaż literacki pt. Miedzianka. Historia znikania znalazł się w finale Nagrody im. R. Kapuścińskiego i był nominowany do Nagrody Literackiej Gdynia 2012; Springer jest również finalistą prestiżowego plebiscytu Nagrody Literackiej Nike w 2012 roku).

Problematyka, którą Springer porusza w swych pracach, dotyczy architektury oraz estetyki architektury. Książka 13 pięter nie jest tu wyjątkiem. Rozprawa składa się z dwóch części, które rozdzielono refleksją na temat szczególnej praktyki - doświadczenia powrotu do miejsc o niegdyś wielkim znaczeniu: „Nie wiem, po co tu jestem. Czasami trzeba po prostu ruszyć do źródła, mimo że rzeka już zupełnie wyschła" ${ }^{2}$ - pisze Springer. Taka jest ta książka.

Pierwszy rozdział jest poruszającym studium na temat rzeczywistości mieszkaniowej międzywojennej Warszawy (powrót do źródła). Ta część nosi tytuł: „Lustro”:

\footnotetext{
${ }^{1}$ S. E. Rasmussen, Odczuwanie architektury, przeł. B. Gadomska, Kraków 2015, s. 12.

${ }^{2}$ F. Springer, 13 pięter, Wołowiec 2015, s. 125.
} 
„15 października - cztery samobójstwa.

17 października - cztery samobójstwa.

29 października. Ulica Marszałkowska 137. Maria Złotnicka, od kilku dni bezrobotna, wchodzi z obojgiem dzieci na ostatnie, piąte piętro kamienicy. Otwiera okno na klatce schodowej. Wyrzuca przez nie najpierw syna, później córkę, na końcu skacze sama”3.

Cytat pochodzi z gazety „Robotnik” (wybrane numery z 1931 roku) i nie opisuje niczego wyjątkowego. Jak wskazuje Springer, prasa była pełna tego rodzaju tragicznych informacji.

13 pięter jest książką, która moim zdaniem intryguje, ponieważ w dobitny sposób pokazuje problemy wynikające z braku przestrzeni do życia oraz z drugiej strony - zmusza czytelnika do zastanowienia nad „naturą” architektury. Rozprawa Springera dotyka więc egzystencji mas ludzkich oraz funkcji, jaką pełni organizowanie przestrzeni za sprawą architektury właśnie.

Trudno jest wyrazić słowami, na jak wielkie niedogodności skazywano wówczas, w międzywojniu, wszystkich tych ludzi (w samej Warszawie było ich około czterdziestu tysięcy), którzy nie byli w stanie opłacić czynszu. Oto, co pisały gazety o jednym $\mathrm{z}$ warszawskich przytułków, do którego prawdopodobnie trafiłaby również bohaterka cytowanego wyżej artykułu: „Gdy są zajęte już wszystkie izby i korytarze, tak, iż o przejściu przez pokotem leżące zwarto obok siebie ciała ludzkie niesposobna pomyśleć, pozostaje jeszcze 150-200 osób, które śpią, stojąc, tworząc żywą kolumnę istot, opierających się jeden obok drugiego” - pisze reporter „Kuriera Warszawskiego”. Jest rok 1925. Artykuł nosi znamienny tytuł $Z$ dna nędzy. Opis ten uzupełnia Springer następującymi słowami: „Mieszkańcami Cyrku są przede wszystkim alkoholicy, żebracy i chorzy psychicznie, niemało jest też kryminalistów, zdarzają się także pozbawieni pracy robotnicy sezonowi i włóczędzy"4. Ale wielki kryzys ekonomiczny i mieszkaniowy miał dopiero nadejść.

Z powagi problemu już u progu lat dwudziestych zdawali sobie sprawę lewicowi działacze, społecznicy, ale też architekci, tacy jak Jan Hampel, Bolesław Bierut, Stanisław Tołwiński, Szymon Judym. Założyli oni Związek Robotniczych Stowarzyszeń Spółdzielczych. W konsekwencji w 1921 r. powstanie Warszawska Spółdzielnia Mieszkaniowa (WSM), pierwsza w stolicy spółdzielnia, której członkowie za cel nadrzędny obiorą zbudowanie kolonii mieszkaniowych dla robotników. Bo, jak słusznie twierdzili Teodor Toeplitz,

3 Tamże, s. 12.

${ }^{4}$ Tamże, s. 24. 
a o czym pisze Springer: „Sprawa mieszkaniowa należy u nas do najbardziej zaniedbanych nie tylko przez rząd będący na usługach klas posiadających, ale też przez samą klasę robotniczą i jej organizację"5. Do realizacji tych socjalistycznych idei w znaczący sposób przyczyni się ławnik miejski Toeplitz. Urzędnik żydowskiego pochodzenia, co wielokrotnie zostanie mu wytknięte przez prawicowe media, zaangażowany społecznik, który z pasją starał się wcielać w życie swe nowoczesne pomysły. Współtwórca budownictwa socjalnego w swych licznych przemówieniach pisał: „Własne mieszkanie jest dla człowieka taką samą koniecznością jak własne buty czy ubranie, którego nikt mu nie ma prawa zabrać [...] Ale ta własność jest w naszym pojęciu własnością użytkową, do której człowiek ma prawo o tyle, o ile jemu i jego rodzinie jest potrzebna do użytku. W żadnym razie ta własność nie może stać się sprawą spekulacji albo źródłem zysku. Dom zbiorowy - przekonuje Toeplitz - musi przodować własnością społeczną, nie może wyjść z rąk spółdzielni, opartej na zasadach użyteczności publicznej”'.

Druga część książki Springera nosi tytuł „Kłamstwo”. Ta część pracy może wydać się zaskakująca, ponieważ ma ona formę dość swobodnego reportażu. Springer stworzył przestrzeń do wypowiedzenia się wszystkim tym, którzy poczuli się oszukani. Na czym miałoby polegać to „kłamstwo”?

Historia Kamili, która została zmuszona zamieszkać w piwnicy, Mariusza i jego rodziny, której - pomimo zupełnie zdawałoby się rozsądnego planu budowy domu - przyszło ostatecznie zamieszkać w murowanym (co nie jest bez znaczenia) garażu. W końcu, historia Bogdana, bezdomnego, który zamieszkał w kontenerze - małym domku, za miastem, z dala od ludzi. To pierwsze $\mathrm{z}$ historii, na jakie natrafi czytelnik w tej części pracy.

Springer za pośrednictwem listów, które otrzymał od nieznajomych ludzi, pokazuje problem szczególnego rodzaju „przemocy architekturą?. Przemoc ta stosowana jest zwykle wobec osób zamieszkujących lokale, które wracają w ręce prywatnych właścicieli. „Czyszczenie kamienic”, bo tak nazywa się ten proceder, okazało się patologią praktykowaną na wielką skalę. Jak wyczyścić „skutecznie” kamienicę z lokatorów, z „wkładki mięsnej”, jak się ich w tym kontekście nazywa? Sposobów jest wiele. Nowy właściciel „bezkarnie” może podwyższyć czynsz o sto, dwieście procent, zażądać opróżnienia strychu i piwnicy. Jeżeli podwyżka nie odniesie skutku, to lokatorów zwykle czeka, ciągłe nachodzenie, groźby, zastraszanie. Później odbywają się tzw. „re-

${ }^{5}$ Tamże, s. 48.

${ }^{6}$ Tamże, s. 63. 
monty”: „Wymontują bramę, drzwi na podwórze i wszystkie okna na klatce schodowej. [...] Na podwórzu zerwą bruk, od ulicy ustawią rusztowania i powieszą na nich szmaty, żeby w mieszkaniach zrobiło się ciemno"7. To nie koniec nękania lokatorów. „Którejś nocy na klatce ktoś odpali petardy i race dymne. Ludzie wybiegną z mieszkań, myśląc, że to pożar. Tego dnia ktoś wytłukł żarówki, więc trzeba schodzić po ciemku, w tym dymie, po schodach, które od kilku dni nie mają już barierek" ${ }^{8}$. Z pewnością można stwierdzić, że „proces czyszczenia” się rozpoczął. Oczywiście to nie wszystkie metody, które stosuje się wobec opornych mieszkańców kamienic, które i tak w większości zostaną ostatecznie zburzone, by zrobić miejsce dla nowych, dużo bardziej opłacalnych inwestycji. Proces ten ma swą naukową nazwę, określa się go pojęciem gentryfikacji. Można by powiedzieć, że naukowcy w przeciwieństwie do urzędników nie wykazali się tak dalece posuniętą ignorancją wobec samego zjawiska - w konsekwencji wobec bólu i cierpienia dziesiątków tysięcy (w skali całego kraju) nękanych ludzi. Ta „przemoc architekturą" niestety okazuje się skuteczna.

Wspinając się piętro po piętrze Springerowskiego bloku, czytelnik napotka historie, które zdają się raz za razem przelewać czar goryczy. Pierwsze piętra opowiadają historie o „zauroczeniu” kredytami w obcych walutach. Springer wskazuje na ułomność prawa, gdzie w tym całym „bałaganie” najlepiej orientują się nie klienci, ale banki i deweloperzy - skutkiem jest wiele nieporozumień i problemów natury społecznej. Gospodarstwa domowe wpędzane są w kłopoty - piętro VII - i historia Pauliny. Sytuacja mieszkaniowa i ekonomiczna przekłada się na relacje międzyludzkie. Z losów bohaterów, które opowiada autor dowiadujemy się, że kredyt hipoteczny „łączy” ludzi bardziej niż jakakolwiek inna forma zobowiązania.

Praca Springera - jakby z dziennikarskiego obowiązku - jest głosem młodych ludzi, którzy domagają się rozwiązania ich problemów. To całkiem zrozumiałe, gdyż jak mówił Toeplitz $\mathrm{w}$ rozmowie $\mathrm{z}$ Tołwińskim i reporterem „Robotnika” Jerzym Gietlingiem: „Tak, widzicie, będzie [...] Nic nie pomoże pisanie o tym, że jest źle i tragicznie, trzeba wskazywać sposoby usunięcia tego zła. Co jest wart lekarz, który stawia diagnozę, ale nie przepisuje leczenia?".

7 Tamże, s. 161.

8 Tamże, s. 162.

9 Tamże, s. 77. 
Springer oddaje głos również ekspertom. Wszyscy oni zdają się apelować, aby wreszcie problem rozwiązać w sposób organiczny, tj. całościowy, a przy tym socjalny, dostrzegając problemy najuboższych. Bo tylko takie całościowe podejście zdolne jest obalić dominujące również współcześnie przekonanie, że mieszkanie kojarzy się z walką o wyegzekwowanie obywatelskiego prawa ${ }^{10}$. Zdaniem Sprignera nie możemy o tym zapomnieć, co więcej, musimy robić wszystko, by prawo do mieszkania stało się prawem każdego obywatela, bez wyjątku.

Rozprawa Springera nie ma charakteru sensu stricto filozoficznego. Jest to raczej książka-manifest, mówiąca o architekturze jako podstawie do egzystencji, trwałym fundamencie do życia. $Z$ pozoru lekka $w$ formie zawiera książka Springera potencjał do snucia refleksji natury filozoficznej właśnie.

Jakub Maciejewski

Uniwersytet Mikołaja Kopernika, Toruń, Polska e-mail: jakub_maciejewski@wp.pl

10 Tamże, s. 267. 